\title{
Improving passive transfer of immunoglobulins in calves. I: Dose effect of feeding a commercial colostrum replacer
}

\author{
S. M. Godden, ${ }^{* 1}$ D. M. Haines, $\ddagger$ and D. Hagman* \\ *Department of Veterinary Population Medicine, University of Minnesota, St. Paul 55108 \\ †Department of Veterinary Microbiology, Western College of Veterinary Medicine, University of Saskatchewan, Saskatoon, Saskatchewan, \\ Canada \\ ¥The Saskatoon Colostrum Co. Ltd., Saskatoon, Canada
}

\section{ABSTRACT}

The objective of this study was to describe the effects of feeding 1 or 2 doses of a commercially available colostrum-derived colostrum replacer (CR) on passive transfer of immunoglobulins $(\mathrm{Ig})$ in newborn dairy calves, including IgG, IgG1, IgG2, IgA, and IgM. Newborn calves were removed from the dam before suckling and randomly assigned to 1 of 3 treatment groups: group 1 were fed 1 package (100 g of $\operatorname{IgG})$ of CR product, group 2 was fed 2 packages (200 g of $\operatorname{IgG}$ ) of the same CR product, and group 3 was fed $3.8 \mathrm{~L}$ of maternal colostrum. All colostrum treatments were fed using an esophageal tube feeder within $2 \mathrm{~h}$ of birth. Blood samples collected before colostrum feeding and at $24 \mathrm{~h}$ of age were tested for serum total protein and Ig concentrations. Mean 24-h serum total protein (TP) and $\operatorname{IgG}$ concentrations were significantly lower for calves in group $1(\mathrm{n}=24 ; \mathrm{TP}=4.9 \mathrm{~g} / \mathrm{dL}, \operatorname{IgG}=9.6$ $\mathrm{mg} / \mathrm{mL}$ ) compared with calves in groups 2 or 3 . There was no difference in 24-h serum TP or IgG concentrations between calves in group $2(\mathrm{n}=23 ; \mathrm{TP}=5.5 \mathrm{~g} /$ $\mathrm{dL}, \operatorname{IgG}=19.0 \mathrm{mg} / \mathrm{mL})$ and calves in group $3(\mathrm{n}=$ $22 ; \mathrm{TP}=5.7 \mathrm{~g} / \mathrm{dL}, \mathrm{IgG}=20.7 \mathrm{mg} / \mathrm{mL}$ ). Fifty-four, 100 , and $91 \%$ of calves in groups 1, 2 and 3 achieved acceptable passive transfer (24-h serum IgG $\geq 10 \mathrm{mg} /$ $\mathrm{mL}$ ), respectively. Statistically significant but numerically small differences existed between calves in groups 2 and 3 for some 24-h serum Ig classes and subclasses (mean serum concentrations of $\operatorname{IgG} 2, \operatorname{Ig} \mathrm{A}, \operatorname{Ig} \mathrm{M}$ ) and for the relative percentages of $\mathrm{Ig}$ classes and subclasses (IgA, IgM, and IgG as a percentage of total Ig; IgG1 and $\operatorname{IgG} 2$ as a percentage of total $\operatorname{IgG}$ ).

Key words: passive transfer, immunoglobulin, colostrum, colostrum replacer

Received October 28, 2008.

Accepted December 13, 2008.

${ }^{1}$ Corresponding author: godde002@umn.edu

\section{INTRODUCTION}

Colostrum management is the single most important management factor determining calf health and survival (McGuirk and Collins, 2004). Calves may be defined as having failure of passive transfer (FPT) of protective colostral immunoglobulins (Ig) if the serum IgG concentration is $<10 \mathrm{mg} / \mathrm{mL}$ when sampled between 24 and $48 \mathrm{~h}$ of age (NAHMS, 1996; Weaver et al., 2000). Unfortunately, many producers continue to incur significant losses associated with FPT. In the United States, mortality rates in preweaned dairy heifers are estimated to range between 7.9 and 11\% (NAHMS, 1993, 1996, 2002, 2007). Failure of passive transfer resulting from poor colostrum management is a key factor contributing to these excessive losses (Wells et al., 1996). These studies point to the need for producers to adopt management practices or technologies to improve colostrum management.

A successful colostrum management program will require producers to consistently provide calves with a sufficient volume of clean, high-quality colostrum within the first few hours of life (McGuirk and Collins, 2004). However, farms can occasionally experience periods when an adequate supply of clean, high-quality fresh or stored colostrum is not available to feed to all newborn calves. Contributing to this shortage, some producers may discard colostrum from cows that test positive to such pathogens as Mycobacterium avium ssp. paratuberculosis, bovine leukosis virus, or Mycoplasma bovis mastitis (McGuirk and Collins, 2004). Under such circumstances, using commercially available colostrum replacement $(\mathbf{C R})$ products may offer producers a convenient way to improve levels of passive immunity while reducing the risk of pathogen exposure through colostrum.

Colostrum replacement products contain bovine Ig that is typically either lacteal- or plasma-derived. To achieve successful passive transfer in the average 43$\mathrm{kg}$ (90-lb) Holstein calf, experts have estimated that producers should feed a minimum mass of $100 \mathrm{~g}$ of IgG in the first colostrum feeding (Besser et al., 1991; Davis 
and Drackley, 1998). As a result, many manufacturers have formulated commercially available $\mathrm{CR}$ to contain between 100 and $130 \mathrm{~g}$ of IgG per dose. However, results evaluating the efficacy of commercial $\mathrm{CR}$ to prevent FPT in calves have produced very mixed, and often unacceptable, results. Although studies have reported that some commercial CR products were successful (Quigley et al., 2001; Jones et al., 2004; Foster et al., 2006), other products failed to achieve average concentrations of $10 \mathrm{mg} / \mathrm{mL}$ IgG in serum of calves fed CR (Mee et al., 1996; Quigley et al., 2001; Smith and Foster, 2007; Swan et al., 2007). Smith and Foster (2007) concluded that simply examining the mass of IgG provided by the $\mathrm{CR}$ is not an adequate measure or predictor of product efficacy, and that each CR product should be properly evaluated for efficacy before use.

One explanation for the inconsistent efficacy of different commercial $\mathrm{CR}$ products among studies may be that the CR simply vary by quality. This could be attributed to differences in manufacturing techniques and quality assurance/testing programs for different $\mathrm{CR}$ products. Another contributing factor may be that the assumption, that a minimum dose of $100 \mathrm{~g}$ of $\mathrm{IgG}$ should be sufficient to achieve adequate passive transfer in the average calf, is incorrect. Another important consideration affecting the ability of a CR to meet passive transfer goals is the target level for passive transfer. In a recent study that assigned a serum IgG value of $13.4 \mathrm{mg} / \mathrm{mL}$ at $48 \mathrm{~h}$ as a target for acceptable passive transfer, Chigerwe et al. (2008) concluded that feeding $100 \mathrm{~g}$ of colostral $\operatorname{IgG}$ by oresophageal intubation was insufficient for achieving this target. They concluded that at least 150 to $200 \mathrm{~g}$ of colostral IgG was required for this level of passive transfer of colostral Ig.

Another unknown is whether calves fed commercial $\mathrm{CR}$ products absorb adequate levels of Ig fractions other than IgG. As IgG is the predominant Ig in colostrum and calf serum, this fraction is most widely reported across studies reporting on passive transfer in calves. Other Ig fractions (e.g., IgG1, IgG2, IgA, IgM) in $\mathrm{CR}$ products are simply assumed to be present at similar concentrations or proportions, relative to total IgG or total Ig, as is found in the original Ig source (e.g., bovine colostrum or plasma). Studies are lacking to describe passive transfer of these other Ig fractions in calves fed commercial CR products.

The first objective of this study was to evaluate the effect of feeding 1 or 2 doses of a commercially available colostrum-based CR product or $3.8 \mathrm{~L}$ of maternal colostrum on measures commonly used to describe success of passive transfer in 24-h-old calves, including serum IgG concentration $(\mathrm{mg} / \mathrm{mL})$, serum total protein concentration (TP, g/dL), apparent efficiency of absorption of $\operatorname{IgG}(\mathbf{A E A}, \%)$, and risk for FPT (defined as serum IgG
$<10.0 \mathrm{mg} / \mathrm{mL}$ ). The second objective was to describe 24-h serum concentrations of a variety of Ig classes and subclasses, including IgG, IgG1, IgG2, IgA and IgM, for calves fed either CR or maternal colostrum.

\section{MATERIALS AND METHODS}

\section{Calf Enrollment and Sampling}

Protocols used to enroll and treat calves within this study were approved by the University of Minnesota Institutional Animal Care and Use Committee (University of Minnesota, Minneapolis). The study was conducted between June and August 2006 on a commercially owned dairy facility that housed 400 dry and transition cows (Emerald Dairy II, Emerald, WI). When calving was imminent, cows were moved from a freestall pen into individual maternity pens. Female calves from observed calvings were removed from the dam within 20 to 30 min of birth and before suckling could occur. To be eligible for enrollment, calves had to be single birthed, weigh $\geq 31.7 \mathrm{~kg}$, and have a calving ease score $\leq 3$ (on a scale of 1 to 5 ).

A 10-mL precolostral sample of blood was collected from the jugular vein using a serum vacutainer tube before colostrum was fed. Calves were then randomly assigned to 1 of 3 treatment groups ( $\mathrm{n}=24$ calves per group). Group 1 calves were fed 1 package (1 dose) of a commercially available CR product (Land O'Lakes Colostrum Replacer; Land O'Lakes Inc., St. Paul, MN). Group 2 calves were fed 2 packages ( 2 doses) of the same $\mathrm{CR}$ product. This is a lacteal-derived USDA-regulated product licensed as a veterinary biologic as an aid in the prevention of failure of passive transfer. Testing of serial samples by the National Veterinary Services Laboratory (Ames, IA) ensures that the product meets the requirements for sale, including microbiologic safety plus having equal to or in excess of $100 \mathrm{~g}$ of IgG in 470 $\mathrm{g}$ of powder (1 dose). The CR was mixed according to manufacturer's label directions. The final volume fed to group 1 and group 2 calves was 1.5 and $3 \mathrm{~L}$, respectively. The calculated concentration of $\mathrm{IgG}$ in the CR mixture fed to group 1 and 2 calves was $66.7 \mathrm{~g} / \mathrm{L}$. Group 3 calves were fed $3.8 \mathrm{~L}$ of maternal colostrum that was harvested from the dam typically between 20 and 60 min postcalving. If colostrum was not available from the dam, stored refrigerated colostrum from one other cow was fed. Colostrum was not tested for quality before feeding. However, a 20-mL sample of the colostrum fed was collected immediately before feeding, labeled (dam ID, calf ID, date), and frozen for later IgG analysis. All calves were fed the colostrum treatment within $2 \mathrm{~h}$ after birth using an esophageal tube feeder. Enrollment data recorded for each calf included calf ID, dam ID, 
birth date, birth time, sex, calving ease score, parity of dam, colostrum treatment group assigned, and time of colostrum feeding. Following the single colostrum feeding, calves were provided with twice-daily feedings of $1.8 \mathrm{~L}$ of a commercial milk replacer containing $22 \% \mathrm{CP}$ (milk protein based) and $20 \%$ crude fat. At $24 \mathrm{~h}$ of age ( $\pm 1 \mathrm{~h})$, a $10-\mathrm{mL}$ postcolostral blood sample was collected from the jugular vein using a serum vacutainer tube.

\section{Sample Analysis}

All frozen colostrum samples for calves in group 3 were transported on ice to the University of Minnesota (St. Paul) for testing for total IgG concentration (mg/ $\mathrm{mL}$ ) using a turbidimetric immunoassay (Olympus AU400e, Olympus America Inc., Melville, NY) using reagents from Midland Bioproducts Corp. (Boone, IA). This measure was used to calculate the total mass of $\mathrm{IgG}$ fed to calves in group 3. The total mass of $\operatorname{IgG}$ ingested by calves in groups 1 and 2 were, according to product label, 100 and $200 \mathrm{~g}$, respectively.

All precolostral $(0$ to $1 \mathrm{~h})$ and postcolostral $(24 \mathrm{~h})$ blood samples collected into serum (red top) vacutainer tubes were refrigerated overnight, centrifuged, and the serum separated within $24 \mathrm{~h}$ of collection. Zero- and 24-h serum TP concentrations $(\mathrm{g} / \mathrm{dL})$ were determined using a commercially available hand-held refractometer method (VET 360, Reichert Inc., Depew, NY). Sera were then frozen at $-20^{\circ} \mathrm{C}$ until submission, on ice, to the Prairie Diagnostic Services Laboratory (University of Saskatchewan, Saskatoon, Canada) for IgG testing. Zero- and 24-h serum IgG samples from calves in all 3 study groups were tested for total IgG concentration $(\mathrm{mg} / \mathrm{mL})$ by means of radial immunodiffusion as described by Chelack et al. (1993). The AEA of IgG (\%), a calculated measure that estimates the proportion of the total IgG mass fed absorbed into the calf's circulation, was calculated using a formula described previously by Quigley et al. (2002), assuming a plasma volume of $9.9 \%$ of birth weight. A calf was defined as having FPT if serum IgG at $24 \mathrm{~h}$ was $<10.0 \mathrm{mg} / \mathrm{mL}$. Twenty-four-hour serum IgA, IgM, IgG1, and IgG2 concentrations $(\mathrm{mg} / \mathrm{mL})$ were measured for calves in treatment groups 2 and 3, using a radioimmunodiffusion assay performed according to the manufacturer's directions (VMRD Inc., Pullman, WA).

\section{Statistical Analysis}

Descriptive statistics were generated to describe calf and dam characteristics, maternal colostrum quality, and calf serum Ig and TP measures for the 3 treatment groups.
Common Measures of Passive Transfer. Linear regression analysis (PROC MIXED, version 9.1; SAS Institute, Cary, NC) was used to describe the relationship between colostrum treatment group (explanatory variable: group $1=1$ dose $\mathrm{CR}$; group $2=2$ doses CR; group $3=3.8 \mathrm{~L}$ colostrum) and each of the continuous dependent variables of interest for calf serum (TP, g/ $\mathrm{dL}$; IgG, mg/mL) at both 0 and $24 \mathrm{~h}$ of age, and AEA (\%) for IgG at $24 \mathrm{~h}$. Logistic regression analysis (PROC GENMOD in SAS, version 9.1) was used to describe the relationship between treatment group and risk for FPT (24-h serum IgG $<10.0 \mathrm{mg} / \mathrm{mL}$ ). Parameters describing cow and calf characteristics, including dam parity (1, $2,3 \ldots)$, calf birth weight $(\mathrm{kg})$, calf age at first feeding (min), and calving ease score (1 to 3 ) were offered as additional covariates into all models. However, as none of these terms were significant predictors of passive transfer, and none interacted with the variable describing colostrum treatment group, they were subsequently removed from all final models. Final significance was declared at $P<0.05$.

Serum Concentrations of Various Ig Classes and Subclasses at 24 h of Age. For calves in groups 2 and 3 , a similar linear regression analysis approach (as described above) was used to describe the relationship between colostrum treatment group (explanatory variable) and each of the following continuous variables of interest: serum IgG (mg/mL and \% of total $\mathrm{Ig}), \operatorname{IgG} 1$ $(\mathrm{mg} / \mathrm{mL}$ and $\%$ of total $\mathrm{IgG}), \operatorname{IgG} 2(\mathrm{mg} / \mathrm{mL}$ and $\%$ of total $\operatorname{IgG}), \operatorname{IgA}(\mathrm{mg} / \mathrm{mL}$ and $\%$ of total $\mathrm{Ig})$, and $\operatorname{IgM}$ $(\mathrm{mg} / \mathrm{mL}$ and $\%$ of total $\mathrm{Ig})$. Total Ig concentration was calculated as the sum of IgA, IgM, and IgG concentrations $(\mathrm{mg} / \mathrm{mL})$.

\section{RESULTS}

Twenty-four calves were originally enrolled into each of the 3 treatment groups. However, 1 calf was omitted from analysis for group 2 because the calving ease score was recorded as 5 , and 2 calves were omitted from analysis from group 3; one because the precolostral serum IgG measure was $>1.0 \mathrm{mg} / \mathrm{mL}$ and the other because a maternal colostrum sample was not available for testing. As such, records from 24, 23, and 22 calves were available for the final analysis in treatment groups 1 , 2 , and 3 , respectively. The mean $( \pm \mathrm{SD})$ IgG concentration in colostrum fed to calves in group 3 was $71.7 \mathrm{mg} /$ $\mathrm{mL}( \pm 30.3$; range 14.6 to $132.9 \mathrm{mg} / \mathrm{mL})$. Dam parity, calving ease score (1 to 3 ), birth weight (kg), and age at colostrum feeding (min) were not different among the 3 treatment groups (Table 1). Similarly, there were no differences among calf groups for precolostral (0-h) serum TP $(\mathrm{g} / \mathrm{dL})$ or serum IgG $(\mathrm{mg} / \mathrm{mL})$ concentrations (Table 2). None of the aforementioned variables 
Table 1. Description of study calves fed 1 or 2 doses of a colostrum replacer (CR) or 3.8 L of maternal colostrum

\begin{tabular}{|c|c|c|c|}
\hline Parameter & \multicolumn{3}{|c|}{ Treatment group } \\
\hline Calves, $\mathrm{n}$ & 24 & 23 & 22 \\
\hline Calving ease score ${ }^{1}$ & $1(1 \text { to } 2)^{\mathrm{a}}$ & $1(1 \text { to } 2)^{\mathrm{a}^{\prime}}$ & $1(1 \text { to } 3)^{\mathrm{a}}$ \\
\hline Birth weight, ${ }^{2} \mathrm{~kg}$ & $37.9 \pm 4.7(31.8 \text { to } 46.3)^{\mathrm{a}}$ & $39.2 \pm 3.8(32.2 \text { to } 48.1)^{\mathrm{a}}$ & $40.4 \pm 4.4(32.7 \text { to } 52.2)^{\mathrm{a}}$ \\
\hline Age at colostrum feeding, ${ }^{2}$ min & $49.9 \pm 19.4(20 \text { to } 112)^{\mathrm{a}}$ & $44.2 \pm 13.3(22 \text { to } 75)^{\mathrm{a}}$ & $44.3 \pm 14.6(20 \text { to } 70)^{\mathrm{a}}$ \\
\hline
\end{tabular}

${ }^{\mathrm{a}-\mathrm{C}}$ Values within row are significantly different $(P<0.05)$.

${ }^{1}$ Median (range).

${ }^{2}$ Mean \pm SD (range).

remained as significant covariates in the final models. However, as predicted, there were significant differences in the total of mass of IgG ingested by calves in the 3 treatment groups (Table 1 ).

\section{Common Measures of Passive Transfer}

Mean $( \pm \mathrm{SD})$ serum TP and serum IgG concentrations at $24 \mathrm{~h}$ were significantly lower for calves in group $1(1$ dose $\mathrm{CR}: \mathrm{TP}=4.9 \pm 0.3 \mathrm{~g} / \mathrm{dL} ; \mathrm{IgG}=9.6 \pm 3.5$ $\mathrm{mg} / \mathrm{mL}$ ) compared with calves in groups 2 or 3 (Table $2)$. Forty-six percent of calves in group 1 were described as having FPT based on the cut-off of $<10 \mathrm{mg} / \mathrm{mL}$ of serum IgG. There was no difference in 24 -h serum TP or IgG concentrations, or in the proportion of calves with serum $\operatorname{IgG}<10 \mathrm{mg} / \mathrm{mL}$, when comparing calves in group $2(2$ doses $\mathrm{CR}$ : TP $=5.5 \pm 0.5 \mathrm{~g} / \mathrm{dL} ; \mathrm{IgG}=$ $19.0 \pm 5.0 \mathrm{mg} / \mathrm{mL} ; \mathrm{FPT}$ proportion $=0 \%$ ) with calves in group $3(3.8 \mathrm{~L}$ of maternal colostrum: $\mathrm{TP}=5.7 \pm$ $0.7 ; \operatorname{IgG}=20.7 \pm 8.4 ;$ FPT proportion $=9 \%$; Table 2). Apparent efficiency of absorption of $\operatorname{IgG}(\%)$ was not different among the 3 treatment groups (group $1=$ $35.5 \pm 11.3 \%$; group $2=36.5 \pm 8.8 \%$; group $3=31.8$ $\pm 11.7 \%)$.

\section{Serum Concentrations of Various Ig Classes and Subclasses at $\mathbf{2 4} h$ of Age}

Because serum IgG concentrations were not different for calves in treatment groups 2 and 3, the serum Ig classes and subclasses in 24-h samples for calves in these 2 groups were also compared (Table 3). Mean total IgG and IgG1 concentrations at $24 \mathrm{~h}$ were not different between calves in group $3(\mathrm{IgG}=20.7 \pm 8.4 \mathrm{mg} /$ $\mathrm{mL}$; IgG1 $=19.5 \pm 7.9 \mathrm{mg} / \mathrm{mL}$ ) versus calves in group $2(\mathrm{IgG}=19.0 \pm 5.0 \mathrm{mg} / \mathrm{mL} ; \mathrm{IgG} 1=17.1 \pm 3.8 \mathrm{mg} /$ $\mathrm{mL})$. Total serum Ig concentration tended to be greater for calves in group $3(24.5 \pm 9.6 \mathrm{mg} / \mathrm{mL})$ versus calves in group $2(20.5 \pm 5.3 \mathrm{mg} / \mathrm{mL})$ but this difference was not significant $(P=0.097$; Table 3$)$. Mean concentrations of $\operatorname{Ig} \mathrm{A}, \operatorname{IgM}$, and IgG2 were significantly greater for calves in group $3(\operatorname{IgA}=1.3 \pm 0.9 \mathrm{mg} / \mathrm{mL} ; \operatorname{IgM}=$ $2.5 \pm 1.2 \mathrm{mg} / \mathrm{mL} ; \operatorname{IgG} 2=1.3 \pm 0.3 \mathrm{mg} / \mathrm{mL}$ ) compared with calves in group $2(\operatorname{IgA}=0.8 \pm 0.3 \mathrm{mg} / \mathrm{mL} ; \operatorname{IgM}=$ $0.7 \pm 2.5 \mathrm{mg} / \mathrm{mL} ; \operatorname{IgG} 2=0.9 \pm 0.1 \mathrm{mg} / \mathrm{mL})$.

When examining $\operatorname{Ig} \mathrm{A}, \operatorname{IgM}$, and $\operatorname{IgG}$ concentrations as a percentage of total Ig, IgG (\% of total Ig) was significantly greater for calves in group $2(92.4 \pm 1.2 \%)$ compared with calves in group 3 (83.9 $\pm 5.4 \%$; Table

Table 2. Measures of passive transfer in serum of calves fed 1 or 2 doses of a colostrum replacer (CR) or $3.8 \mathrm{~L}$ of maternal colostrum (mean \pm $\mathrm{SD}$, with range in parentheses)

Treatment group

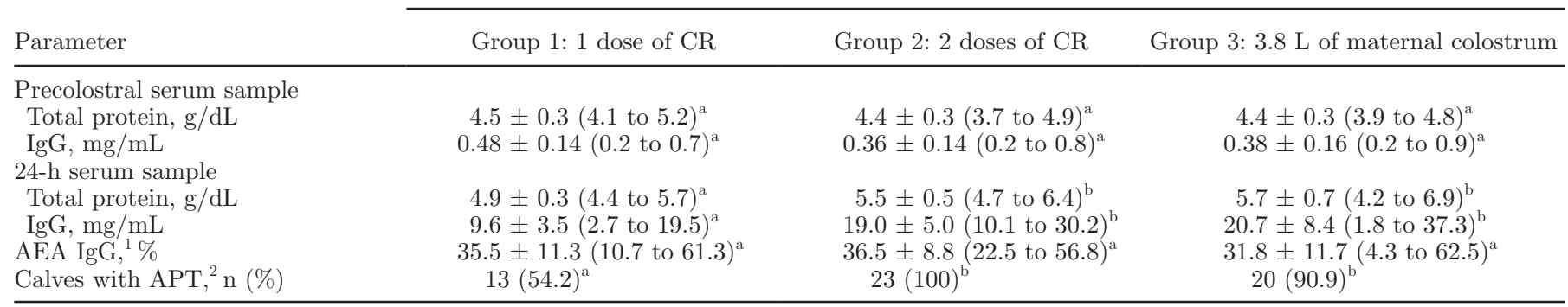

${ }^{\mathrm{a}, \mathrm{b}}$ Values within row are significantly different $(P<0.05)$.

${ }^{1} \mathrm{AEA}=$ apparent efficiency of absorption of IgG.

${ }^{2} \mathrm{APT}=$ adequate passive transfer (serum $\mathrm{IgG}$ at $24 \mathrm{~h} \geq 10.0 \mathrm{mg} / \mathrm{mL}$ ). 
Table 3. Serum immunoglobulin classes and subclasses at $24 \mathrm{~h}$ in calves fed 2 doses of a colostrum replacer (CR) or $3.8 \mathrm{~L}$ of maternal colostrum (mean $\pm \mathrm{SD}$, with range in parentheses)

\begin{tabular}{|c|c|c|c|}
\hline \multirow[b]{2}{*}{ Parameter } & \multicolumn{2}{|c|}{ Treatment group } & \multirow[b]{2}{*}{$P$-value } \\
\hline & Group 2: 2 doses of $\mathrm{CR}$ & Group 3: 3.8 L of maternal colostrum & \\
\hline \multicolumn{4}{|l|}{ Concentration, $\mathrm{mg} / \mathrm{mL}$} \\
\hline Total Ig ${ }^{1}$ & $20.5 \pm 5.3(11.1$ to 32.1$)$ & $24.5 \pm 9.6(2.6$ to 40.3$)$ & 0.097 \\
\hline $\operatorname{IgA}$ & $0.8 \pm 0.3(0.5$ to 1.8$)$ & $1.3 \pm 0.9(0.3$ to 4.1$)$ & 0.033 \\
\hline $\operatorname{IgM}$ & $0.7 \pm 0.2(0.4$ to 1.3$)$ & $2.5 \pm 1.2(0.3$ to 5.7$)$ & $<0.0001$ \\
\hline $\operatorname{IgG} 2$ & $0.9 \pm 0.1(0.7$ to 1.1$)$ & $1.3 \pm 0.3(0.6$ to 1.8$)$ & $<0.0001$ \\
\hline \multicolumn{4}{|l|}{ Percentage } \\
\hline $\mathrm{IgA}, \%$ of total $\mathrm{Ig}$ & $3.9 \pm 0.6(2.8$ to 5.7$)$ & $5.4 \pm 3.1(1.7$ to 12.6$)$ & 0.028 \\
\hline $\mathrm{IgM}, \%$ of total Ig & $3.7 \pm 0.7(2.2$ to 5.1$)$ & $10.7 \pm 3.7(4.4$ to 19.2$)$ & $<0.0001$ \\
\hline $\mathrm{IgG}, \%$ of total Ig & $92.4 \pm 1.2(90.3$ to 94.5$)$ & $83.9 \pm 5.4(69.2$ to 92.6$)$ & $<0.0001$ \\
\hline IgG1, \% of $\operatorname{IgG}$ & $94.9 \pm 0.7(93.3$ to 96.0$)$ & $92.3 \pm 5.8(70.0$ to 95.9$)$ & 0.041 \\
\hline $\operatorname{IgG} 2, \%$ of IgG & $5.1 \pm 0.7(4.0$ to 6.7$)$ & $7.7 \pm 5.8(4.1$ to 30.0$)$ & 0.041 \\
\hline
\end{tabular}

${ }^{1}$ Total $\operatorname{Ig}=(\operatorname{Ig} \mathrm{A}+\operatorname{IgM}+\operatorname{IgG})$.

3). Conversely, $\operatorname{Ig} \mathrm{A}$ and $\operatorname{IgM}(\%$ of total $\operatorname{IgG}$ ) were significantly greater for calves in group $3(\operatorname{IgA}=5.4$ $\pm 3.1 \% ; \operatorname{IgM}=10.7 \pm 3.7 \%)$ compared with calves in group $2(\operatorname{Ig} \mathrm{A}=3.9 \pm 0.6 \% ; \operatorname{IgM}=3.7 \pm 0.7 \%)$. When examining IgG1 and IgG2 concentrations as a relative percentage of total IgG $(\mathrm{mg} / \mathrm{mL}), \operatorname{IgG} 1$ (\% of total $\operatorname{IgG})$ was significantly greater for calves in treatment group $2(94.9 \pm 0.7 \%)$ compared with calves in group 3 $(92.3 \pm 5.8 \%$; Table 3$)$.

\section{DISCUSSION}

\section{Common Measures of Passive Transfer}

Because AEA of IgG (\%) was not different among the 3 study groups, the treatment differences observed for group 1 are most likely attributable to the fact that the total mass of $\operatorname{IgG}(\mathrm{g})$ ingested was considerably less for calves in group 1 (100 g of IgG fed) compared with the other 2 colostrum treatment groups (group $2=200 \mathrm{~g}$ of $\mathrm{IgG}$; group $3=271 \mathrm{~g}$ of $\mathrm{IgG}$ ). The dose response to total mass (g) of IgG fed observed in this study has been reported in some previous studies of CR products (Quigley et al., 2001; Jones et al., 2004; Foster et al., 2006). For example, in a recent study that tested the same commercial $\mathrm{CR}$ as was evaluated in the current study, the average 24 -h serum IgG level for calves fed 1 dose (100 g of IgG) or 2 doses (200 g of $\mathrm{IgG}$ ) of $\mathrm{CR}$, or $3.8 \mathrm{~L}$ of maternal colostrum were 11.6, 16.9 , and $27.2 \mathrm{mg} / \mathrm{mL} \mathrm{IgG}$, respectively (Foster et al., 2006). Feeding a lower mass of $\operatorname{IgG}$ (e.g., 90 to $125 \mathrm{~g}$ of $\operatorname{IgG}$ ) may be one factor contributing to several previous studies of other CR that reported that CR failed to consistently achieve the target of $10 \mathrm{mg} / \mathrm{mL}$ IgG in serum of calves (Mee et al., 1996; Quigley et al., 2001;
Swan et al., 2007). However, Smith and Foster (2007) correctly stated that simply examining the total mass of $\mathrm{IgG}$ provided by a $\mathrm{CR}$ is not an adequate predictor of product efficacy. This was made abundantly clear in a recent study wherein feeding 2 doses (100 g of $\operatorname{IgG}$ ) or 3 doses (150 g of IgG) of a different commercial CR than the product tested in the current study resulted in FPT in 95 and $76 \%$ of calves, respectively (compared with only $5 \%$ FPT in calves fed $3.8 \mathrm{~L}$ of maternal colostrum). As such, each CR product should be evaluated for efficacy before use (Smith and Foster, 2007).

The cumulative findings from this and previous studies emphasize the need for veterinarians, manufacturers, and other industry specialists to better educate producers to ensure realistic expectations when feeding commercial CR products. Given that $3.8 \mathrm{~L}$ of good-quality colostrum $(50 \mathrm{~g} / \mathrm{L})$ would provide $190 \mathrm{~g}$ of $\mathrm{IgG}$ to the calf, it is unrealistic for veterinarians and producers to expect a single dose of any CR product containing only $100 \mathrm{~g}$ of IgG to perform equally well. In a recent study that defined serum $\mathrm{IgG}$ of $13.4 \mathrm{mg} / \mathrm{mL}$ at $48 \mathrm{~h}$ as the target for acceptable passive transfer, Chigerwe et al. (2008) concluded that feeding $100 \mathrm{~g}$ of colostral IgG by oresophageal intubation was insufficient for adequate passive transfer of colostral immunoglobulins. Chigerwe et al. (2008) concluded that at least 150 to $200 \mathrm{~g}$ of colostral IgG was required to meet this level of passive transfer of colostral immunoglobulins. Veterinarians and producers need to appreciate that when experts recommend that a minimum of $100 \mathrm{~g}$ of $\operatorname{IgG}$ be fed to calves, this is the calculated minimum dose required to achieve serum $\operatorname{IgG} \geq 10.0 \mathrm{mg} / \mathrm{mL}$ in the average calf fed under optimal conditions with respect to timing and other factors that might affect the absorption of IgG. And because serum IgG measures are typically 
normally distributed, this implies that approximately half of all calves will experience FPT if an average of only $10 \mathrm{mg} / \mathrm{mL}$ of $\operatorname{IgG}$ is reached for the group. If a producer's goal is for $\geq 90 \%$ of calves to meet or exceed a target of $10 \mathrm{mg} / \mathrm{mL}$ (or approximate serum TP value of 5.0 or $5.2 \mathrm{~g} / \mathrm{dL}$; Calloway et al., 2002), then the target mean serum IgG concentration for the group of calves must be significantly higher than $10 \mathrm{mg} / \mathrm{mL}$. It is also germane to this discussion to consider whether using a target cut-off of $10 \mathrm{mg} / \mathrm{mL}$ serum IgG for acceptable passive transfer is optimal. Although this cut-off has been recommended in several publications (Besser et al., 1991; NAHMS 1993; McGuirk and Collins, 2004), it can be argued that, depending upon farm management, the optimum serum IgG concentration could be substantially lower or higher for individual farms. Several studies have suggested that a more optimal cut-off to define adequate passive transfer in calves at $48 \mathrm{~h}$ is a serum IgG concentration $\geq 13.4 \mathrm{mg} / \mathrm{mL}$ (Tyler et al., 1996, 1998; Virtala et al., 1999)

\section{Serum Concentrations of Various Ig Classes and Subclasses at $24 h$ of Age}

Although serum TP and total IgG levels are useful and commonly used measures of passive transfer and protection from neonatal disease, colostrum provides many other nutritional factors and specific and nonspecific immune factors that may influence short- and long-term health and performance of the animal (Foley and Otterby, 1978; Kehoe et al., 2007). Immunoglobulin $\mathrm{G}$, IgA, and IgM account for approximately 85 to 90,5 , and $7 \%$, respectively, of the total Ig in colostrum, with $\operatorname{IgG}_{1}$ accounting for 80 to $90 \%$ of the total $\operatorname{IgG}$ (Larson et al., 1980). Although relative concentrations are highly variable among cows and studies, one study reported that mean colostral concentrations of $\mathrm{IgG}$, $\operatorname{IgA}$, and $\operatorname{IgM}$ were $75,4.4$, and $4.9 \mathrm{mg} / \mathrm{mL}$, respectively (Newby et al., 1982). Because calves are born agammaglobulinemic, we might expect the relative composition of various serum Ig fractions measured in calves at $24 \mathrm{~h}$ of age to be similar to that found in the colostrum consumed. Evaluation of consumption of CR products or maternal colostrum that results in optimizing these other parameters should also be considered. As such, the second objective of the current study was to describe 24-h serum concentrations of Ig classes and subclasses in calves fed a colostrum-derived CR or maternal colostrum.

Because serum total IgG concentrations were not statistically different for calves in treatment groups 2 and 3 , these 2 groups were compared. When examining absolute concentrations of $\mathrm{Ig}$ fractions in calf serum at $24 \mathrm{~h}$, concentrations of total Ig, IgG, and IgG1 were numerically higher but not statistically different for calves fed maternal colostrum (vs. calves fed 2 doses of $\mathrm{CR}$ ). Concentrations of $\operatorname{IgG} 2, \operatorname{Ig} \mathrm{A}$, and $\operatorname{IgM}$ were both numerically and statistically higher in serum of calves fed maternal colostrum. Although other factors may have contributed to these differences, the most likely explanation is that a greater total mass of all of these Ig fractions was fed to calves fed maternal colostrum (vs. calves fed 2 doses of CR). Even though testing of these other Ig fractions was not conducted on the maternal colostrum or CR samples themselves, the mean IgG mass consumed by colostrum-fed calves was $271 \mathrm{~g}$ (vs. $200 \mathrm{~g}$ for CR-fed calves). However, if the observed treatment differences in concentrations of $\mathrm{Ig}$ fractions were simply because of differences in absolute mass of Ig fed, it would be expected that the relative proportions of the various Ig fractions should be similar in the serum of calves fed CR compared with calves fed maternal colostrum, but this was not the case in the current study. The proportion of total Ig that was $\operatorname{IgG}$ and the proportion of total IgG that was IgG1 were significantly greater for calves fed 2 doses of CR compared with calves fed 3.8 L of maternal colostrum. Conversely, the proportion of total IgG that was IgG2 and the proportion of total Ig that was IgA or IgM were significantly less for calves fed 2 doses of CR compared with calves fed $3.8 \mathrm{~L}$ of maternal colostrum. We cannot explain why these differences in the relative proportions of Ig fractions were observed in CR-fed calves. It is possible that the bovine colostrum originally used to manufacture the CR differed somewhat in its Ig composition compared with the maternal colostrum fed on the single study herd used for this research project, or that the different Ig classes may be affected differently during the CR manufacturing process. This hypothesis requires further testing.

It is interesting to compare the results of the current study to those of a previous study that similarly compared various serum Ig fractions in calves fed either one dose of a plasma-derived $\mathrm{CR}$ product (approximately $100 \mathrm{~g}$ of IgG ingested) or $3.8 \mathrm{~L}$ of maternal colostrum (mean $249 \mathrm{~g}$ of IgG ingested; Johnson, 2007). In that study serum concentrations of $\operatorname{IgG}, \operatorname{IgA}, \operatorname{IgM}, \operatorname{IgG} 1$, and $\operatorname{IgG} 2$ were statistically and numerically greater for calves fed maternal colostrum than for calves fed the plasma-derived CR. This was largely attributed to large differences in the total mass of Ig being fed between the 2 groups. However, the IgG1:IgG2 ratio was approximately $69 \%: 31 \%$ for plasma-derived CR-fed calves compared with 79\%:21\% for maternal colostrum-fed calves (Johnson, 2007). By comparison, the IgG1:IgG2 ratios achieved in the current study were 92\%:8\% and 95\%:5\% for colostrum-fed calves and colostrum-derived CR-fed calves, respectively. The differences in serum 
IgG1:IgG2 ratios for calves fed a plasma-derived CR versus a colostrum-derived $\mathrm{CR}$ could be attributed to the fact that colostrum is known to contain predominantly $\operatorname{IgG} 1$ ( 80 to $90 \%$ of total $\operatorname{IgG}$ ), whereas plasma contains approximately equal proportions of IgG1 and IgG2 (Davis and Drackley, 1998). It is not known if the numerically small shifts in serum Ig fractions found in calves fed the colostrum-derived $\mathrm{CR}$ in the current study or if the larger differences in serum Ig fractions found in plasma-derived CR-fed calves in a previous study (Johnson, 2007) are likely to affect calf health or performance. In particular, given the resecretion of colostral IgG1 at mucosal surfaces (Besser et al., 1987) it is likely that protection from diarrhea and pneumonia resides in this subclass and thus the natural preponderance of IgG1 in colostrum may have originally evolved for this purpose. The relative efficacy and clinical relevance to the calf of CR products containing high levels of IgG2 compared with those containing predominantly IgG1 requires further testing. Colostral IgM and IgA (in contrast to $\operatorname{IgG1}$ ) are not actively concentrated from the plasma into the mammary gland during colostrogenesis; rather, the source of those components is local production within the mammary gland. There are many other factors present in colostrum that are likely of value to the neonate including insulin-like growth factor 1, epidermal growth factor, and the metabolic stimulation provided by the unique properties of colostral fat. Further studies to assess the presence and biological activity of these factors in $\mathrm{CR}$ products and in maternal colostrum, if subjected to treatments such as on-farm pasteurization, will be important.

One treatment difference worth noting in the current study was that feeding 2 packages of CR resulted in considerably less variation in 24 -h serum TP, IgG, IgG1, IgG2, IgA, and IgM concentrations compared with calves fed maternal colostrum. This is expected because the mass of IgG delivered to calves in the CR groups would be relatively consistent. By comparison, maternal colostrum quality was highly variable. Even though the average mass of IgG delivered to colostrumfed calves was $271 \mathrm{~g}$, the range was between 55 and 502 $\mathrm{g}$ for individual calves. The reduced variation in serum IgG, and thus specific antibody titers, might be considered an advantage for feeding CR (vs. maternal colostrum) if producers are attempting to standardize calf vaccination management, as there may be less variation in the duration of interference due to maternal antibodies. This hypothesis deserves investigation. Perhaps more importantly however, these results should serve to remind the industry of how variable colostrum quality can be because even among calves fed $3.8 \mathrm{~L}$ of maternal colostrum within $2 \mathrm{~h}$ of birth, $9 \%$ of calves had serum IgG levels $<10 \mathrm{mg} / \mathrm{mL}$. Veterinarians should assist producers to implement management strategies known to improve colostrum quality (e.g., dry period length, dry cow vaccination, rapid harvest of colostrum after calving; Dixon et al., 1961; Moore et al., 2005; Rastani et al., 2005) and to monitor the colostrum management program (McGuirk and Collins, 2004).

\section{CONCLUSIONS}

When fed using an esophageal tube feeder, feeding one dose (100 g of IgG) of a colostrum-derived CR resulted in lower serum IgG levels and unacceptably high FPT rates compared with feeding $3.8 \mathrm{~L}$ of maternal colostrum. Feeding 2 doses ( $200 \mathrm{~g}$ of $\mathrm{IgG}$ ) of the same CR resulted in very high serum IgG levels and no cases of FPT, results equivalent to feeding $3.8 \mathrm{~L}$ of high quality maternal colostrum. Statistically significant but numerically small differences existed between CR-fed and colostrum-fed calves for some Ig classes and subclasses (i.e., serum concentrations of $\operatorname{Ig} \mathrm{G} 2, \operatorname{Ig} \mathrm{A}, \operatorname{IgM}$ ) and for their relative percentages $(\operatorname{Ig} \mathrm{A}, \operatorname{IgM}$, and $\operatorname{IgG}$ as a percentage of total Ig; IgG1 and IgG2 as a percentage of total $\operatorname{IgG}$ ). If CR products are to be used on a dairy, producers need to make an informed decision, based on their target for passive transfer rates, on the quantity or number of doses of CR to feed. Because of the highly variable performance among different $\mathrm{CR}$ products, veterinarians should not extrapolate findings of studies of one CR product to other products and should review results of peer-reviewed controlled trials before recommending a $\mathrm{CR}$ product to client producers.

\section{ACKNOWLEDGMENTS}

Financial support for this study was provided by the Minnesota Rapid Agricultural Response Fund. Financial and in-kind support was also provided by the Saskatoon Colostrum Company (Saskatoon, Saskatchewan, Canada).

\section{REFERENCES}

Besser, T. E., C. C. Gay, and L. Pritchett. 1991. Comparison of three methods of feeding colostrum to dairy calves. J. Am. Vet. Med. Assoc. 198:419-422.

Besser, T. E., T. C. McGuire, and C. C. Gay. 1987. The transfer of serum IgG1 antibody into the gastrointestinal tract in newborn calves. Vet. Immunol. Immunopathol. 17:51-56.

Calloway, C. D., J. W. Tyler, R. K. Tessman, and D. Hostetler. 2002. Comparison of refractometers and test endpoints in the measurement of serum protein concentration to assess passive transfer status in calves. J. Am. Vet. Med. Assoc. 221:16051608

Chelack, B. J., P. S. Morley, and D. M. Haines. 1993. Evaluation of methods for dehydration of bovine colostrum for total replacement of normal colostrum in calves. Can. Vet. J. 34:407-412.

Chigerwe, M., J. W. Tyler, L. G. Schultz, J. R. Middleton, B. J. Steevens, and J. N. Spain. 2008. Effect of colostrum administration 
by use of oroesophageal intubation on serum IgG concentrations in Holstein bull calves. Am. J. Vet. Res. 69:1158-1163.

Davis, C. L., and J. K. Drackley. 1998. Colostrum. Pages 179-206 in The Development, Nutrition, and Management of the Young Calf. 1st ed. Iowa State University Press, Ames.

Dixon, F. J., W. O. Weigle, and J. J. Vasquez. 1961. Metabolism and mammary secretion of serum protein in the cow. Lab. Invest. 10:216-237.

Foley, J. A., and D. E. Otterby. 1978. Availability, storage, treatment, composition, and feeding value of surplus colostrum: A review. J. Dairy Sci. 61:1033-1060.

Foster, D. M., G. W. Smith, T. R. Sanner, and G. V. Busso. 2006. Serum IgG and total protein concentrations in dairy calves fed two colostrum replacement products. J. Am. Vet. Med. Assoc. 229:1282-1285.

Johnson, J. 2007. Pages 33-57 in The effect of different colostrum management strategies on passive transfer of cellular and humoral immune parameters in Holstein calves. MS Thesis. University of Minnesota, St. Paul.

Jones, C. M., R. E. James, J. D. Quigley, and M. L. McGilliard. 2004 Influence of pooled colostrum or colostrum replacement on $\operatorname{IgG}$ and evaluation of animal plasma in milk replacer. J. Dairy Sci. 87:1806-1814.

Kehoe, S. I., B. M. Jayarao, and A. J. Heinrichs. 2007. A survey of bovine colostrum composition and colostrum management practices on Pennsylvania dairy farms. J. Dairy Sci. 90:4108-4116.

Larson, B. L., H. L. Heary Jr., and J. E. Devery. 1980. Immunoglobulin production and transport by the mammary gland. J. Dairy Sci. 63:665-671.

McGuirk, S. M., and M. Collins. 2004. Managing the production, storage and delivery of colostrum. Vet. Clin. North Am. Food Anim. Pract. 20:593-603.

Mee, J. F., K. J. O'Farrell, P. Reitsma, and R. Mehra. 1996. Effect of a why protein concentrate used as a colostrum substitute or supplement on calf immunity, weight gain, and health. J. Dairy Sci. 79:886-889.

Moore, M., J. W. Tyler, M. Chigerwe, M. E. Dawes, and J. R. Middleton. 2005. Effect of delayed colostrum collection on colostral $\operatorname{IgG}$ concentration in dairy cows. J. Am. Vet. Med. Assoc. 226:1375-1377.

National Animal Health Monitoring System. 1993. National Dairy Heifer Evaluation Project. Dairy Herd Management Practices Focusing on Preweaned Heifers. USDA-APHIS Veterinary Services, Ft. Collins, CO.

National Animal Health Monitoring System. 1996. Dairy 1996 National Dairy Health Evaluation Project. Dairy heifer morbidity, mortality, and health management focusing on preweaned heifers. USDA-APHIS Veterinary Services, Ft. Collins, CO.

National Animal Health Monitoring System. 2002. Dairy 2002. Part 1: Reference of Dairy Health and Management in the United States. USDA-APHIS Veterinary Services, Ft. Collins, CO.

National Animal Health Monitoring System. 2007. Dairy 2007. Part 1: Reference of Dairy Health and Management in the United States. USDA-APHIS Veterinary Services, Ft. Collins, CO.

Newby, T. J., C. R. Stokes, and F. J. Bourne. 1982. Immunological activities of milk. Vet. Immunol. Immunopathol. 3:67-94.

Quigley, J. D. C. J. Kost, and T. M. Wolfe. 2002. Absorption of protein and $\operatorname{IgG}$ in calves fed a colostrum supplement or replacer. J. Dairy Sci. 85:1243-1248.

Quigley, J. D. III, R. E. Strohbehn, C. J. Kost, and M. M. O'Brien. 2001. Formulation of colostrum supplements, colostrums replacers and acquisition of passive immunity in neonatal calves. J. Dairy Sci. 84:2059-2065.

Rastani, R. R., R. R. Grummer, S. J. Bertics, A. Gümen, W. Wiltbank, D. Mashek, and M. C. Schwab. 2005. Reducing dry period length to simplify feeding transition cows: Milk production, energy balance and metabolic profiles. J. Dairy Sci. 88:1004-1014.

Smith, G. W., and D. M. Foster. 2007. Short communication: Absorption of protein and immunoglobulin G in calves fed a colostrum replacer. J. Dairy Sci. 90:2905-2908.

Swan, H., S. Godden, R. Bey, S. Wells, J. Fetrow, and H. ChesterJones. 2007. Passive transfer of immunoglobulin $g$ and preweaning health in Holstein calves fed a commercial colostrum replacer. J. Dairy Sci. 90:3857-3866.

Tyler, J. W., D. D. Hancock, S. M. Parish, D. E. Rea, T. E. Besser, S. G. Sanders, and L. K. Wilson. 1996. Evaluation of 3 assays for failure of passive transfer in calves. J. Vet. Intern. Med. 10:304307.

Tyler, J. W., D. D. Hancock, S. E. Wiksie, S. L. Holler, J. M. Gay, and C. C. Gay. 1998. Use of serum protein concentration to predict mortality in mixed-source dairy replacement heifers. J. Vet. Intern. Med. 12:79-83.

Virtala, A. M., Y. T. Gröhn, G. D. Mechor, and H. N. Erb. 1999 The effect of maternally derived immunoglobulin $\mathrm{G}$ on the risk of respiratory disease in heifers during the first 3 months of life. Prev. Vet. Med. 39:25-37.

Weaver, D. M., J. W. Tyler, D. C. VanMetre, D. E. Hostetler, and G. M. Barrington. 2000. Passive transfer of colostral immunoglobulins in calves. J. Vet. Intern. Med. 14:569-577.

Wells, S. J., D. A. Dargatz, and S. L. Ott. 1996. Factors associated with mortality to 21 days of life in dairy heifers in the United States. Prev. Vet. Med. 29:9-19. 